\title{
Prophylaxis of deep-vein thrombosis after lower extremity amputation. Comparison of low molecular weight heparin with unfractionated heparin ${ }^{1}$
}

\author{
Profilaxia da trombose venosa profunda após amputação de membros inferiores. \\ Comparação entre heparina de baixo peso molecular e heparina não fracionada.
}

\author{
Sidney Lastória², Hamilton A. Rollo², Winston Bonetti Yoshida ${ }^{3}$, Mariangela Giannini², Regina Moura², Francisco H. A. \\ Maffei $^{4}$ \\ 1. Research from Department of Surgery and Orthopedics of the School of Medicine of Botucatu (SMB), Paulista State University \\ (UNESP), São Paulo. Brazil. \\ 2. Assistant Professor of the Department of Surgery and Orthopedics, SMB, UNESP, São Paulo. Brazil. \\ 3. Associate Professor of the Department of Surgery and Orthopedics, SMB, UNESP, São Paulo. Brazil. \\ 4. Full Professor of the Department of Surgery and Orthopedics, SMB, UNESP, São Paulo. Brazil.
}

\begin{abstract}
Purpose: To compare the efficacy and safety of a low molecular weight heparin (enoxaparin) with unfractionated heparin (UH) in this prophylaxis. Methods: Seventy five patients (59 men and 16 women), undergoing major lower extremity amputation (30 above-knee and 45 below-knee), were randomized to be treated with subcutaneous UH (5,000 IU t.i.d.) or enoxaparin (40mg/day) during hospitalization. Prophylaxis was started 12 hours before surgery or, in emergency cases, in the first postoperative day. Results: The two groups were comparable with regard to baseline characteristics. Evaluation of DVT was performed by daily clinical examination and by duplex scanning before and 5 to 8 days after surgery. DVT was documented in the operated limb in $9.75 \%$ in patients treated with enoxaparin and in $11.76 \%$ in patients treated with UH $(p=0.92)$ and there was one bilateral thrombosis in each group. Bleeding complications were not observed in both groups. Conclusion: Enoxaparin and UH were both efficient and safe for the prophylaxis of DVT in patients submitted to lower extremity amputation.
\end{abstract}

Key words: Amputation. Venous Thrombosis. Heparin, Low-Molecular-Weight. Prevention \& Control .

\section{RESUMO}

Objetivo: Comparar a eficácia e segurança da profilaxia com heparina de baixo peso molecular (enoxaparina) versus heparina não fracionada (HNF). Métodos: Setenta e cinco pacientes (59 homens e 16 mulheres ), submetidos a amputação maior dos membros inferiores (30 acima do joelho e 45 abaixo do joelho ), foram tratados ao acaso com HNF subcutânea (5,000 IU -2x/dia ) ou enoxaparina subcutânea (40mg/dia ) durante a hospitalização. A profilaxia teve início 12 horas antes da cirurgia ou , em casos emergenciais, no primeiro dia de pós-operatório. Resultados: Os dois grupos de tratamento foram comparáveis em termos de características gerais . A avaliação da TVP foi feita por meio de exame clínico diário e pelo mapeamento dúplex antes e 5-8 dias após a cirurgia . A TVP foi documentada no lado operado em 9,75\% dos pacientes tratados com enoxaparina e em 11,76\% dos pacientes tratados com HNF ( $\mathrm{p}=0,92)$ e houve um caso de TVP bilateral em cada grupo . Sangramentos não foram verificados nos 2 grupos. Conclusão: A enoxaparina e HNF foram igualmente eficientes e seguras para a profilaxia da TVP em pacientes submetidos à amputação de membros inferiores .

Descritores: Amputação. Trombose Venosa. Heparina de Baixo Peso Molecular. Prevenção \& Controle.

\section{Introduction}

Venous thromboembolism (VTE) is very common among surgical patients. It causes significant lower-limb morbidity and may lead to death in the form of massive pulmonary embolism. Without prophylaxis, deep vein thrombosis occurs in approximately $25 \%$ of patients submitted to general surgery $^{1}, 51 \%$ of elective hip replacements , $47 \%$ of total knee replacements and $45 \%$ of hip fractures ${ }^{2}$. Limited data are available on the prevalence of VTE after lower-limb amputations . In 87 patients undergoing 96 major lower extremity amputations for ischemia, Barnes and Slaymarker ${ }^{3}$ found no instance of major leg vein thrombosis and only one episode of a small non-fatal pulmonary embolus in a patient suffering trauma to the amputation stump after discharge from the hospital. Surveillance of DVT was carried out with Doppler ultrasound in only 35 patients. Yeager et $\mathrm{al}^{4}$. documented DVT in $12.5 \%$ of 72 patients submitted to lower-limb amputation (one bilateral, four ipsilateral, and four contralateral to amputation). Burke et $\mathrm{al}^{5}$. found evidence of DVT in the thigh in four of the eight patients after a below-knee amputation. In a previous study we found $38 \%$ of deep-vein thrombosis (DVT) in 50 consecutive 
patients after major amputation of lower extremity, diagnosed by duplex scanning, being $26 \%$ occlusive and $12 \%$ partial $^{6}$. The high frequencies reported would justify the use of prophylaxis in this kind of patient. However, to our knowledge, there have been no previous studies involving thrombo-prophylaxis in amputees. So, the objective of the present study was to prospectively compare the efficacy and safety of a low molecular weight heparin (enoxaparin) with unfractionated heparin (UH) in the prophylaxis of deep-vein thrombosis after lower-limb amputation.

\section{Methods}

The present study was a randomized clinical trial, openlabel, performed during one year, from 1995 to 1996, with seventy five consecutive patients who agreed to participate in it and signed the informed consent. Approval was given by the Institutional Ethical Committee. The inclusion criteria were: patients over 18 years, undergoing elective or emergency lower-limb amputation for critical-limb ischemia and signature of the informed consent. The exclusion criteria were previous venous thrombo-embolism , refusal to participate and patients with contra-indication for anticoagulant prophylaxis. Fifty nine men and 16 women with critical-limb ischemia and undergoing major lowerextremity amputation (30 above-knee and 45 below-knee) were randomized to be treated with subcutaneous UH (5,000 IU t.i.d.) or enoxaparin (40mg/day) during hospitalization. The randomization process was serial numbered envelopes, prepared by someone not involved with the study. Prophylaxis was started 12 hours before surgery or, in emergency cases, on the first postoperative day. Post surgical management of amputation in our Hospital included stump bandaging which were changed daily for inspection of the stump and of the incision. Pain, discomfort, swelling of legs and respiratory difficulties were observed every day. Evaluation of DVT was performed by daily clinical examination and by duplex scanning (DS) before and 5 to 8 days after surgery. Diagnostic criteria were abnormal venous flow and evidence of an intraluminal thrombi confirmed with compressive ultrasonography. When inconclusive, the duplex scanning was repeated before discharge. Patients found to have a DVT were treated appropriately with intravenous unfractionated heparin or subcutaneous low molecular weight heparin and warfarin. Duplex scanning was performed by two vascular ultrasonographists blinded to the prophylactic treatment prescribed for the patients. The calculated number of patients was sufficient for $90 \%$ statistical power. The statistical difference between the 2 groups was calculated by the Fisher test, with 5\% significance level. The statistical software used was EpiInfo version $6.04^{7}$.

\section{Results}

All patients agreed to sign the informed consent and no one withdrew the consent . The age of the patients varied from 18 to 86 years old. The two groups were comparable with baseline characteristics (Table 1). No thrombophilic state was investigated in these patients. Thirty-four patients were randomized to $\mathrm{UH}$ and 41 to enoxaparin and 4 patients developed DVT in each group (11.76\% and 9.75\% respectively, $\mathrm{p}=0.92$ ), one bilateral in each group. The level of amputation did not influence the incidence. Among 30 patients with amputations at the thigh level, 5 developed DVT, and among 45 patients with amputations below the knee, 3 had DVT . Sex also did not influence the incidence of DVT. There were 7 DVT in 59 male patients (11.8\%) and 1 DVT among 16 female patients (6.2\%) . No bleeding complications were found in any group.

TABLE 1 - Frequency of DVT according to sex, amputation level and treatment groups

\begin{tabular}{lllccc}
\hline Characteristics & Group & $\mathrm{n}$ & $\mathrm{DVT}$ & $\%$ & $\mathrm{p}$ \\
\hline Sex & Female & 16 & 1 & 6.2 & \\
& Male & 59 & 7 & 11.8 & 0.85 \\
Level of & Thigh amputation & 30 & 5 & 16.6 & 0.32 \\
amputation & Leg amputation & 45 & 3 & 6.6 & 11.7 \\
Prophylaxis & UH Treatment & 34 & 4 & 9.7 & 0.92 \\
treatment & LMWH Treatment & 41 & 4 & & \\
& Total of patients & 75 & & & \\
\hline
\end{tabular}

\section{Discussion}

Previous studies have reported varied results, with the incidence of DVT ranging from $0 \%$ to $67 \%$ after lower-limb amputation $^{3-5,8}$. The high incidence reported by Harper et al. ${ }^{8}$ may be attributed to the use of an indwelling catheter to perform phlebography in all patients, which is itself a known risk factor for DVT. On the other hand, the low incidence found by Barnes and Slaymaker ${ }^{3}$ may be explained by the use of Duplex ultrasound in only 35 of the 96 patients enrolled in their study. In the study of Yeager et $\mathrm{al}^{4}$, about $14 \%$ of the patients were already receiving Coumadin which might interfere with their results. In the study of Burke et al. ${ }^{5}$ the number of patients enrolled was small $(n=8)$. In our previous study ${ }^{6}, 50$ consecutive patients were routinely examined by Duplex scanning between the $5^{\text {th }}$ and $7^{\text {th }}$ postoperative day. The ages of the patients varied from 29 to 89 years old, among which were enrolled 29 males and 21 
females. Indications for amputation were critical-limb ischemia in 44 cases, infection in 4 and trauma in 2. Occlusive DVT was found in 13 patients (26\% of the cases) and partial venous thrombi was seen in 6 (12\%), with an overall incidence of DVT in $38 \%$ of the patients. The incidence found was similar to general surgery risk ${ }^{2}$, which would justify the use of prophylaxis in this kind of patient. The diagnosis of DVT with Duplex Scan, combining compression plus color-Doppler , accelerates the examination and improves accuracy, but presents some limitations in detecting recent thrombus formation $^{9}$. It requires a great deal of training and can be technically demanding, particularly in amputation patients, because the impossibility of performing leg blood flow increasing maneuvers, and because of surgical edema. Anyway , in the present study, DVT screening with DS was particularly useful in this type of patients. The best method for DVT screening would be phlebography, but it was difficult to use due to the amputation. There are several risk factors that may predispose amputees to DVT, including sluggish blood flow proximal to the ligated veins and surgical endothelial trauma to the veins. Auto antibodies to phospholipids has been reported in about $26 \%$ of patients undergoing general vascular surgery ${ }^{10}$. Thrombophilic state was not previously investigated in amputated patients. The absence of data up to now on thrombo-prophylaxis for amputees precludes any recommendation on the type of the prophylactic method to be used. We have chosen UH and enoxaparin, extrapolating the results from studies on general and orthopedic surgery prophylaxis ${ }^{11}$. Our results show that both prophylactic regimens were equally effective in reducing the incidence of post-operative DVT from about $26 \%$ to $9.7-11.7 \%$, which is similar to overall reduction of DVT incidence with low dose subcutaneous heparin in general surgery ( from $25.9 \%$ to $8.6 \%$ ), ${ }^{11}$. Other drugs used for thrombo- prophylactic purposes include: oral anticoagulants, heparinoids, antiplatelets, Dextran $^{2}$ but, as well as heparins, they have not been studied previously in DVT prevention after amputation surgery. Obviously, mechanical prophylactic methods could not be applied in these patients on the operated legs.

\section{Conclusion}

Enoxaparin and UH were equally effective and safe for the prophylaxis of DVT in patients with critical-limb ischemia submitted to lower-limb amputation.

\section{References}

1. Clagett GP, Reisch JS. Prevention of venous thromboembolism in general surgical patients. Results of meta-analysis. Ann Surg. 1988; 208: 227-40.

2. Nicolaides A, Breddin HK, Fareed J, Goldhaber S, Haas S, Hull R, Kalodiki E, Myers K, Samama M, Sasahara A. Prevention of venous thromboembolism. J Vasc Br. 2002; 1:133-70.

3. Barnes RW, Slaymaker EE. Postoperative deep vein thrombosis in the lower extremity amputee: A prospective study with Doppler ultrasound. Ann Surg. 1976; 183: 429-32.

4. Yeager RA, Moneta GL, Edwards JM, Taylor LM, Jr., McConnell DB, Porter JM. Deep vein thrombosis associated with lower extremity amputation. J Vasc Surg. 1995; 22: 612-5.

5. Burke B, Kumar R, Vickers V, Grant E, Scremin E. Deep vein thrombosis after lower limb amputation. Am J Phys Med Rehabil 2000; 79: 145-9.

6. Lastoria S, Rollo H, Yoshida W, Nogueira F, Moura R, Makyama H, Maffei F. Venous thrombosis in amputation stump. International Congress of Phlebology. Corfu, Greece; 1996.

7. WHO-CDC. Epi-info: 6.04 Edition. Atlanta; 2004.

8. Harper DR, Dhall DP, Woodruff PW. Prophylaxis in iliofemoral venous thrombosis. The major amputee as a clinical research model. Br J Surg. 1973; 60: 831.

9. Wells PS, Hirsh J, Anderson DR, Lensing AW, Foster G, Kearon C, Weitz J, Cogo A, Prandoni P, Minuk T. Comparison of the accuracy of impedance plethysmography and compression ultrasonography in outpatients with clinically suspected deep vein thrombosis. A two centre paired-design prospective trial. Thromb Haemost. 1995; 74: 1423-7.

10. Taylor Jr LM, Chitwood RW, Dalman RL, Sexton G, Goodnight SH, Porter JM. Antiphospholipid antibodies in vascular surgery patients: a cross-sectional study. Ann Surg. 1994; 220: 544-50.

11. Geerts WH, Pineo GF, Heit JA, Bergqvist D, Lassen MR, Colwell CW, Ray JG. Prevention of venous thromboembolism: the Seventh ACCP Conference on Antithrombotic and Thrombolytic Therapy. Chest. 2004; 126: 338S-400S.

\section{Correspondence:}

Sidney Lastoria

Universidade Estadual Paulista

Faculdade de Medicina de Botucatu

Depto de Cirurgia e Ortopedia

18618-970 Botucatu-SP Brazil

Phone: (55 14)3811-6269

Fax:(5514)3815-7428

sidlast@fmb.unesp.br
Conflict of interest: none Financial source: Paulista State University

Received: December 10, 2005

Review: January 18, 2006

Accepted: February 05, 2006

\section{How to cite this article:}

Lastória S, Rollo HA, Yoshida WB, Giannini M, Moura R, Maffei FHA. Prophylaxis of deep-vein thrombosis after lower extremity amputation. Comparison of low molecular weight heparin with unfractionated heparin. Acta Cir Bras. [serial on the Internet] 2006 May-June 21(3). Available from URL: http://www.scielo.br/acb. 